generator. After a few minutes the generator is replaced by a scintillation counter to estimate the vanadium -52 activity.

In geochemistry, where the study of natural radioactivity has been of prime importance for more than half a century, the new possibilities offered by activation analysis have been welcomed. A powerful technique for age determination in rocks and meteorites depends on measurement of the relative abund ance of parent and daughter nuclides in a natural radioactive decay process. Useful improvement in sensitivity can be expected where one or both of the nuclides can be subjected to activation analysis. Potassium/argon and rubidium/strontium ratios are readily measured in this way. Uranium-238 can be estimated down to a limit of $10^{-12} \mathrm{gm}$. by the reaction ${ }^{238} \mathrm{U}(n, \gamma \beta)^{239} \mathrm{~Np}$. For uranium-235 the limit of sensitivity so far achieved (at the Argonne National Laboratory) is $5 \times 10^{-11} \mathrm{gm}$., using the reaction ${ }^{235} \mathrm{U}(n, f){ }^{140} \mathrm{Ba}$.

Activation analysis of biological material has attracted relatively little attention, though the method has many interesting potentialities. Several elements, including vanadium, manganese and cobalt, are important to plants or animals but their function in human nutrition is still obscure, through lack of sufficiently sensitive analytical methods. The role of vanadium in dental caries and of manganese in bone formation were two of the subjects suggested for study by activation analysis. Many problems in dental science and in animal biochemistry are also awaiting exploration by activation methods.

Arsenic is an element of continuing interest in clinical science, partly because of its increasing uses and hazards in agriculture and partly because it is the only component of tobacco smoke known to be carcinogenic in man. Arsenic-levels in normal tissue are too low for accurate estimation in living subjects by conventional methods. Activation analysis has been used in several investigations of arsenic poisoning, whether accidental or homicidal. An unusual toxicological experiment was the recent study by activation analysis of the remains of Erik XIV, a sixteenth-century Swedish king who died in mysterious circumstances. These tests gave support to the theory that he was poisoned by mercury, said to have been administered in a dish of pea soup.

Although thermal neutrons are the most versatile agents for activation analysis, fast neutrons have some distinctive applications. The estimation of traces of oxygen has been done satisfactorily by mixing the experimental sample with lithium fluoride and irradiating with fast neutrons to produce the reaction ${ }^{6} \mathrm{Li}(n, \alpha){ }^{3} \mathrm{H}$ followed by ${ }^{18} \mathrm{O}\left({ }^{3} \mathrm{H}, n\right){ }^{18} \mathrm{~F}$ (halflife $112 \mathrm{~min}$.). The limit of sensitivity of this method, as practised at Harwell, is $5 \times 10^{-7} \mathrm{gm}$. of oxygen. Protons have been used for the estimation of boron in silicon, a test of considerable importance to transistor manufacturers. Neutron activation yields no suitable isotopes but fast protons induce the reac. tion ${ }^{11} \mathrm{~B}(p, n){ }^{11} \mathrm{C}$ (half-life $20.4 \mathrm{~min}$.). The silicon provides an internal standard by the reaction ${ }^{30} \mathrm{Si}(p, n)^{30} \mathrm{P}$. Concentrations of boron as low as 1 in $10^{9}$ have been measured in this way. Proton activation is useful also for the estimation of boron in germanium. Deuterons provide the best method for the estimation of magnesium in iron, by the reaction ${ }^{24} \mathrm{Mg}(d, \alpha)^{22} \mathrm{Na}$. An internal standard is given by the reaction ${ }^{56} \mathrm{Fe}(d, \alpha)^{54} \mathrm{Mn}$.

Two conclusions emerged from the symposium. The first is that any laboratory using conventional methods of chemical or spectrographic analysis would do well to explore the possible advantages of activation methods for some of its work. The second is that activation analysis, though superficially a simple technique, requires considerable skill in nuclear physics and in analytical chemistry for the full realization of its possibilities.

The success of the meeting was enhanced by the genial hospitality of the sponsors and by the agreeable atmosphere of the magnificent new conference suite of the International Atomic Energy Agency in the Hofburg. The proceedings of the symposium will be published shortly in book form. A longawaited manual of experimental procedures is in an advanced state of preparation at Oak Ridge.

J. M. A. LeniHaN

\title{
THE CAPE TOWN SCIENCE EXHIBITION, 1959
}

$\mathrm{E}^{\mathrm{n}}$ NCOURAGED by the success of the Science Exhibition held in Cape Town in March 1958, the Cape Council of the South African Association for the Advancement of Science, in collaboration with the Royal Society of South Africa, organized the second Science Exhibition in more spacious surroundings $(10,500$ sq. ft.) during the period April 6-11. After introductory addresses by the chairman of the Organizing Committee and vice-president of the South African Association for the Advancement of Science, Dr. Ronald Singer, and by H.M. Astronomer at the Cape, Prof. R. H. Stoy, the Exhibition was officially opened on the evening of April 6 before a distinguished audience of scientists, industrialists and educationists by His Excellency the GovernorGeneral, Dr. E. G. Jansen.

Dr. Jansen stated that the Exhibition must be of particular interest to the layman, "because although one does not always understand all that science has to teach us, one realizes the importance of seience and scientific research especially in the troublous times in which we live, and where science has, to a large extent, changed the life of civilized man and touches our everyday life at every point".

Dr. Jansen indicated that it is a rather startling thought that, according to some reports, the Soviet Union is more advanced than any other country, not only in certain fields of scientific research but also in the number of men and women receiving education and training in science and scientific methods. "The question arises as to whether sufficient is being done in that direction in our country. . . . If we believe that the future of the country is in the hands of the youth of to-day, we should surely see to it that the education of our boys and girls is in the hands of men and women most fitted for the task, and who are devoted to their work. It follows that they should 
be adequately remunerated and enjoy fair conditions of employment."

The organizing committee produced a handsome brochure of 48 pages, providing not only a guide to the twenty-seven exhibits but also a general description of the scientific methods behind each exhibit. In the introduction, Dr. Singer stated that "the Exhibition is an attempt to present to the lay-public interesting aspects of modern scientific research and the application of science to industry and commerce. Some, if not most, of the important research projects and applications of research to industry in South Africa have been carefully assembled for the public of Cape Town and environs. A wider understanding of scientific endeavour and its vast potential will inspire lay individuals and give them some insight into the multitude of problems besetting almost every aspect of our daily lives-which we generally take for granted. Ignorance of these matters must only provide a false sense of security - an 'acceptance without contemplation' which can only end in a degeneration of our standards of civilization".

The exhibits (fixed at twenty-seven because of the limitations of space) were of three types--pure science, applied research and modern technical equipment. The South African Council for Scientific and Industrial Research presented a display depicting the nature and scope of its nine national research laboratories (roughly as outlined in Nature, 183, 853; 1959), a demonstration on the electrodialysis process for desalting water, and a poster-demonstration of the theme "The Planet Earth", emphasizing the international character of the recent International Geophysical Year. The methods of geophysical research were dramatically illustrated. The United Kingdom Information Office presented an impressive display outlining Britain's role in the development of power from the atom. Models of Calder Hall and Zeta provided the basis of the exhibit.

The Division of Fisheries presented its integrated programme of pelagic fish research, indicating the types of problem investigated and the directions in which the research has progressed. It clearly outlined the essential part it played in the $£ 15$ million fishing industry. In addition, the Fishing Industry Research Institute at the University of Cape Town provided an exhibit covering three aspects of its research-electrical thermometers on board ships, protein analysis and the bacteriology of fish.

The South African Broadcasting Corporation provided a unique studio to display the great deal of research and development work that lies behind a modern transmission system. The methods used to minimize distortion and noise were demonstrated. The South African Railways and Harbours' exhibits demonstrated centralized traffic control, the draught arrangement and problems in modern locomotives and the ultrasonic testing of materials.

The tellurometer microwave system of precise measurement of distance (an electronic device which measures distance between a master unit at one end and a remote unit at the other by phase comparison of a number of pattern frequencies) was invented in South Africa and is now used in many parts of the world. This was one of the exhibits by $a$ number of industrial and commercial firms, including modern methods of sock-making, the scientific aspects of a modern motor-car, echo-sounders, industrial closed-circuit television, automatic alarm oquipment on sea-going vessels, modern metal-spraying equipment, prevention of corrosion, atomic power in the oil industry, the bacteriology of canned foods, the standardizing of colours of printing inks, etc.

The South African Trigonometrical Survey exhibited the methods and techniques in modern survey operations. The Division of Entomology indicated the more important aspects of two of its research projects on forest and timber insects. Dr. S. H. Skaife exhibited his ingenious and simple equipment used in studying the habits and nature of some of the 400 species of ants in South Africa. The South African Museum's exhibit demonstrated a 14-ft. fibre-glass cast of a slab of rock containing the footprints of three mammal-like reptiles which lived 200 million years ago in Basutoland.

The South African Association for the Advancement of Knowledge and Culture displayed methods of promoting science education.

The most dramatic and most popular exhibit was that of the Department of Surgical Research of the University of Cape Town, which had a working heart-lung machine, and films and slide demonstrations on open-heart surgery : approximately twenty people a day were treated for syncope by the St. John Ambulance Brigade.

Films of scientific interest were screened through. out the daily 12-hr. period when the Exhibition was open in a specially erected cinema inside the hall.

Approximately 17,000 people of all races visited the Exhibition, in comparison with 5,000 who attended the 1958 Exhibition. As a result of the sale of the brochure and the renting of exhibition space to commercial firms, more than $£ 1,200$ was collected. Most of this money will form the basis of a fund to provide scholarships to suitably qualified young men and women who wish to take up science as a career.

This Exhibition is part of an ambitious programme on which the Cape Council of the South African Association for the Advancement of Science has embarked during the past three years to stimulate an interest in and an understanding of the progress of modern science among non-specialists and laymen. The Council organizes four to five science film shows a month which attract capacity audiences, and, in addition, fortnightly Iuncheon film shows are put on at the South African Museum (where there is at present also a planetarium attracting visitors). Through the Council's initiative, refresher courses for' science teachers are now regularly provided at the major South African universities, and at present the first in a series of autumn lectures (based on the Christmas Lectures in the United Kingdom) is being arranged for senior pupils at schools in and around Cape Town. Regular conversaziones are held, and last year the Council organized the Darwin-Wallace centenary week of oxhibitions, lectures and symposia on evolution. A special committee is investigating science teaching, and particularly mathematics, in schools and making recommendations for improve. ment to the educational authorities. The formation of a Parliamentary and Scientific Committee is being mooted, and the Cape Council is already planning for the Diamond Jubilee Congress of the Association in 1962, when it hopes to invite distinguished scientists from overseas.

The Cape Council of the South African Association for the Advancement of Science firmly believes that in providing these services to the lay public it will eventually produce noticeable effects on the future leaders of not only science but also polities, religion, ethics and moral philosophy. Ronald SINGER 